2016

\title{
Caddo Ceramic Vessels from the E. B. Minter (41HP2) and Roger Attaway (41HP15) Sites in Hopkins County, Texas
}

Timothy K. Perttula

Heritage Research Center, Stephen F. Austin State University

Mark Walters

Heritage Research Center, Stephen F. Austin State University

Follow this and additional works at: https://scholarworks.sfasu.edu/ita

Part of the American Material Culture Commons, Archaeological Anthropology Commons, Environmental Studies Commons, Other American Studies Commons, Other Arts and Humanities Commons, Other History of Art, Architecture, and Archaeology Commons, and the United States History Commons

Tell us how this article helped you.

This Article is brought to you for free and open access by the Center for Regional Heritage Research at SFA ScholarWorks. It has been accepted for inclusion in Index of Texas Archaeology: Open Access Gray Literature from the Lone Star State by an authorized editor of SFA ScholarWorks. For more information, please contact cdsscholarworks@sfasu.edu. 


\section{Caddo Ceramic Vessels from the E. B. Minter (41HP2) and Roger Attaway (41HP15) Sites in Hopkins County, Texas}

\section{Creative Commons License}

\section{(c) (1) \&}

This work is licensed under a Creative Commons Attribution-NonCommercial 4.0 International License 


\title{
Caddo Ceramic Vessels from the E. B. Minter (41HP2) and Roger Attaway (41HP15) Sites in Hopkins County, Texas
}

\author{
Timothy K. Perttula and Mark Walters
}

\section{INTRODUCTION}

A number of ancestral Caddo ceramic vessels are in the collections at the Texas Archeological Research Laboratory at the University of Texas at Austin from the E. B. Minter (41HP2, n=4 vessels) and Roger Attaway (41HP15, n=5 vessels) in Hopkins County, Texas. We recently had the opportunity to fully document these vessels as part of our long-term efforts to characterize ancestral East Texas Caddo vessel forms, temper usage, and stylistic/decorative elements.

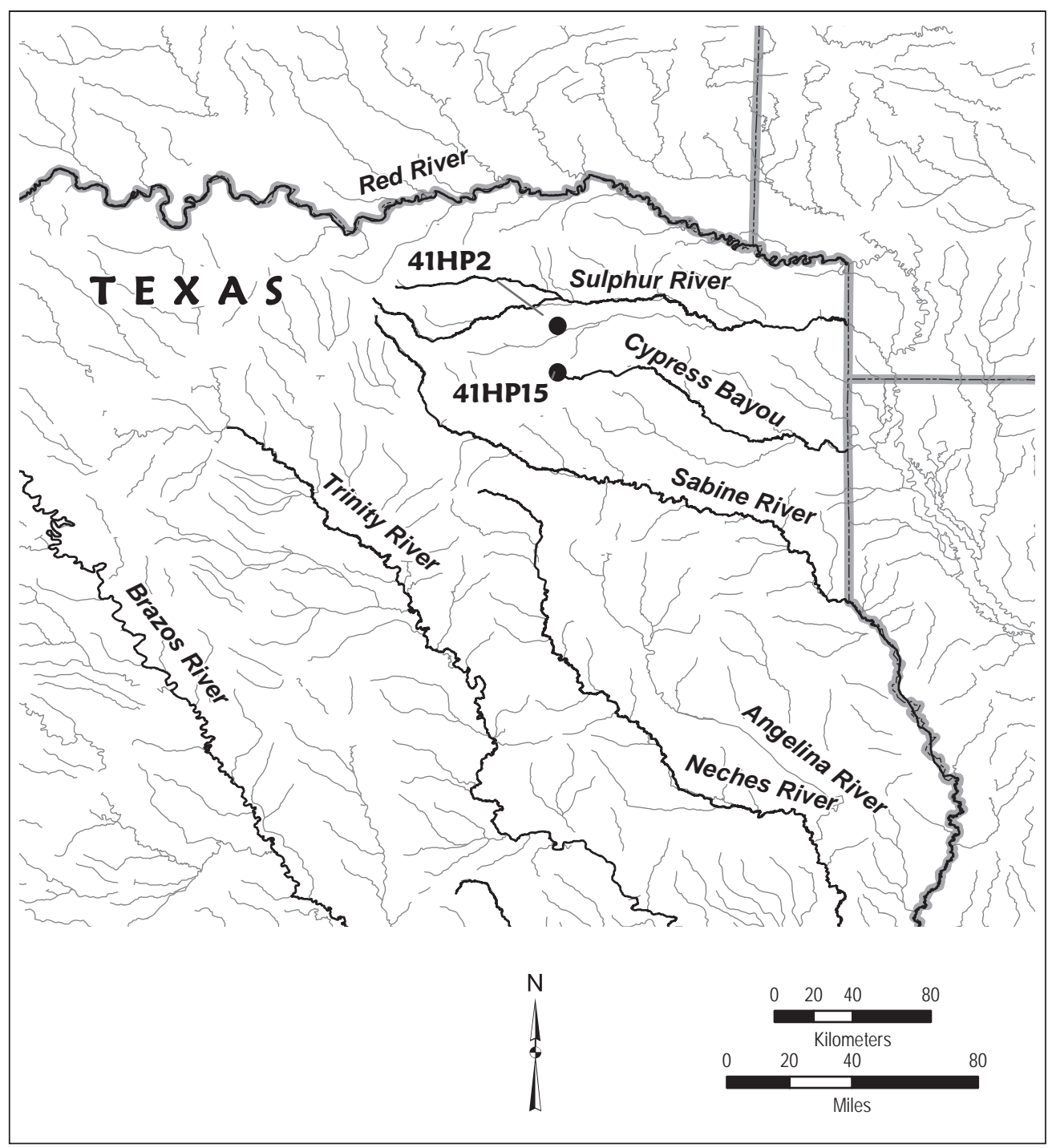

Figure 1. Location of the E. B. Minter (41HP2) and Roger Attaway (41HP15) sites in East Texas. 
The University of Texas conducted excavations at the E. B. Minter site, in the upper White Oak Creek and Sulphur River basin, in May 1931 (Jackson 1931). A 60 x $35 \mathrm{ft}$. area was excavated on a sandy knoll at that time based on a report that ceramic vessels and ceramic pipes had been found there in years past, but no features were found. A second area by a county road exposed Burial 1 at a depth of ca. $77 \mathrm{~cm}$ bs; Jackson (1931) noted that ceramic vessels had been found in this area months earlier by road grading work along the road. Burial 1 was laid out in an east-west orientation.

The Roger Attaway Farm site (41HP15) was located in the Spring of 1929 when heavy rains exposed a Caddo burial with five ceramic vessels and two arrow points. This site was 2 miles northwest of Black Oak, in the upper Caney Creek valley in the upper Sabine River basin. Mr. Attaway collected the exposed funerary objects, and then gave them to a Mr. George E. Cowan. Cowan sold four of the vessels to the University of Texas shortly thereafter.

\section{E. B. Minter (41HP2) Vessel Documentation}

SITE NAME OR SITE NUMBER: E. B. Minter

VESSEL NO.: 11

VESSEL FORM: Carinated bowl

NON-PLASTICS AND PASTE: grog

RIM AND LIP FORM: Direct rim and rounded lip

CORE COLOR: F (fired in a reducing environment and cooled in the open air)

INTERIOR SURFACE COLOR: yellowish-brown; fire clouds on the rim, body, and base

EXTERIOR SURFACE COLOR: yellowish-brown; fire clouds on the rim, body, and base

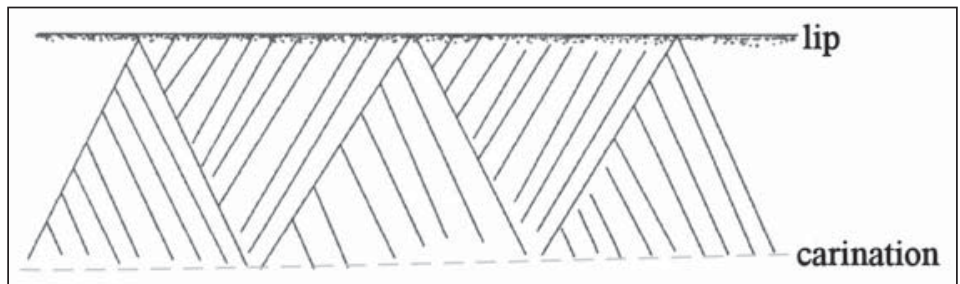

Figure 2. Decorative elements on Sanders Engraved carinated bowl from the E. B. Minter site (41HP2).

WALL THICKNESS (IN MM): rim, $6.2 \mathrm{~mm}$

INTERIOR SURFACE TREATMENT: smoothed

EXTERIOR SURFACE TREATMENT: burnished

HEIGHT (IN CM): 14.0

ORIFICE DIAMETER (IN CM): 27.8

DIAMETER AT BOTTOM OF RIM OR NECK (IN CM): 27.6

BASE DIAMETER (IN CM) AND SHAPE OF BASE: 11.5; circular and flat

ESTIMATED VOLUME (IN LITERS): 3.5 
DECORATION (INCLUDING MOTIF AND ELEMENTS WHEN APPARENT): the rim is decorated with a continuous series of diagonal opposed lines and alternating engraved triangles around the vessel (Figure 2).

PIGMENT USE AND LOCATION ON VESSEL: red clay pigment in the engraved lines

TYPE AND VARIETY (IF KNOWN): Sanders Engraved

SITE NAME OR SITE NUMBER: E. B. Minter

VESSEL NO.: 12, Burial 1

VESSEL FORM: Bottle

NON-PLASTICS AND PASTE: grog

RIM AND LIP FORM: Missing

CORE COLOR: $\mathrm{G}$ (fired in a reducing environment and cooled in the open air)

INTERIOR SURFACE COLOR: grayish-brown

EXTERIOR SURFACE COLOR: yellowish-brown; fire clouds on the body and base

WALL THICKNESS (IN MM): body, $5.6 \mathrm{~mm}$; base, $7.6 \mathrm{~mm}$

INTERIOR SURFACE TREATMENT: none

EXTERIOR SURFACE TREATMENT: none

HEIGHT (IN CM): 7.6+

ORIFICE DIAMETER (IN CM): N/A

DIAMETER AT BOTTOM OF RIM OR NECK (IN CM): 8.9 (body)

BASE DIAMETER (IN CM) AND SHAPE OF BASE: 7.0; circular and rounded

ESTIMATED VOLUME (IN LITERS): N/A

DECORATION (INCLUDING MOTIF AND ELEMENTS WHEN APPARENT): Plain

PIGMENT USE AND LOCATION ON VESSEL: none

TYPE AND VARIETY (IF KNOWN): Unidentified plain ware 
SITE NAME OR SITE NUMBER: E. B. Minter

VESSEL NO.: 13

VESSEL FORM: Bowl

NON-PLASTICS AND PASTE: grog

RIM AND LIP FORM: Direct rim and rounded lip

CORE COLOR: F (fired in a reducing environment and cooled in the open air)

INTERIOR SURFACE COLOR: yellowish-brown; fire clouds on the body and base

EXTERIOR SURFACE COLOR: yellowish-brown; fire clouds on the rim, body, and base

WALL THICKNESS (IN MM): rim, $5.7 \mathrm{~mm}$

INTERIOR SURFACE TREATMENT: none

EXTERIOR SURFACE TREATMENT: smoothed

HEIGHT (IN CM): 5.7

ORIFICE DIAMETER (IN CM): 14.6

DIAMETER AT BOTTOM OF RIM OR NECK (IN CM): N/A

BASE DIAMETER (IN CM) AND SHAPE OF BASE: 7.6; circular and flat

ESTIMATED VOLUME (IN LITERS): 0.3

DECORATION (INCLUDING MOTIF AND ELEMENTS WHEN APPARENT): Plain

PIGMENT USE AND LOCATION ON VESSEL: none

TYPE AND VARIETY (IF KNOWN): Unidentified plain ware 
SITE NAME OR SITE NUMBER: E. B. Minter

VESSEL NO.: 14

VESSEL FORM: Carinated bowl

NON-PLASTICS AND PASTE: grog

RIM AND LIP FORM: Direct rim and flat lip; lip notched

CORE COLOR: $\mathrm{G}$ (fired in a reducing environment and cooled in the open air)

INTERIOR SURFACE COLOR: grayish-brown

EXTERIOR SURFACE COLOR: yellowish-brown; fire clouds on the rim, body, and base

WALL THICKNESS (IN MM): rim, $6.9 \mathrm{~mm}$; body, $7.6 \mathrm{~mm}$

INTERIOR SURFACE TREATMENT: none

EXTERIOR SURFACE TREATMENT: none

HEIGHT (IN CM): 10.8

ORIFICE DIAMETER (IN CM): 22.8

DIAMETER AT BOTTOM OF RIM OR NECK (IN CM): 22.8

BASE DIAMETER (IN CM) AND SHAPE OF BASE: 10.8; circular and flat

ESTIMATED VOLUME (IN LITERS): 1.5

DECORATION (INCLUDING MOTIF AND ELEMENTS WHEN APPARENT): The rim has a continuous series of alternating engraved triangles filled with diagonal lines pitched in opposing directions (Figure 3).

PIGMENT USE AND LOCATION ON VESSEL: none

TYPE AND VARIETY (IF KNOWN): Sanders Engraved

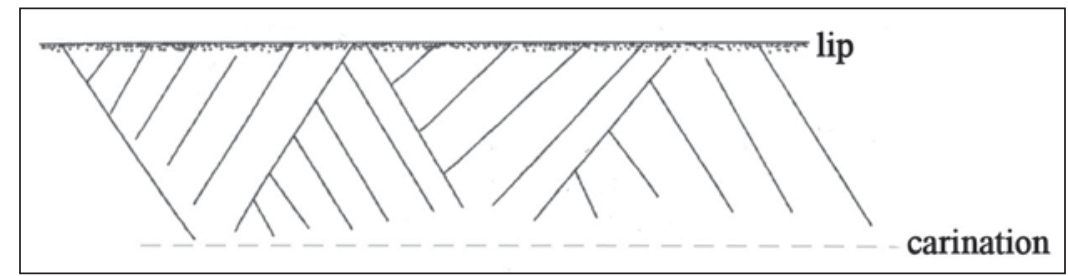

Figure 3. Decorative elements on Sanders Engraved carinated bowl from the E. B. Minter site. 
SITE NAME OR SITE NUMBER: Roger Attaway

VESSEL NO.: 1

VESSEL FORM: Bottle

NON-PLASTICS AND PASTE: grog

RIM AND LIP FORM: Direct rim and rounded lip

CORE COLOR: F (fired in a reducing environment and cooled in the open air)

INTERIOR SURFACE COLOR:

yellowish-brown

EXTERIOR SURFACE COLOR:

yellowish-brown; fire clouds on the

body and base

WALL THICKNESS (IN MM): rim, $5.6 \mathrm{~mm}$

INTERIOR SURFACE TREATMENT: none

EXTERIOR SURFACE TREATMENT:

smoothed

HEIGHT (IN CM): 21.0

ORIFICE DIAMETER (IN CM): 4.8

DIAMETER AT BOTTOM OF RIM OR

NECK(INCM): 7.4; maximum body diameter of $16.0 \mathrm{~cm}$.

BASE DIAMETER (IN CM) AND

SHAPE OF BASE: 6.2 ; circular and flat

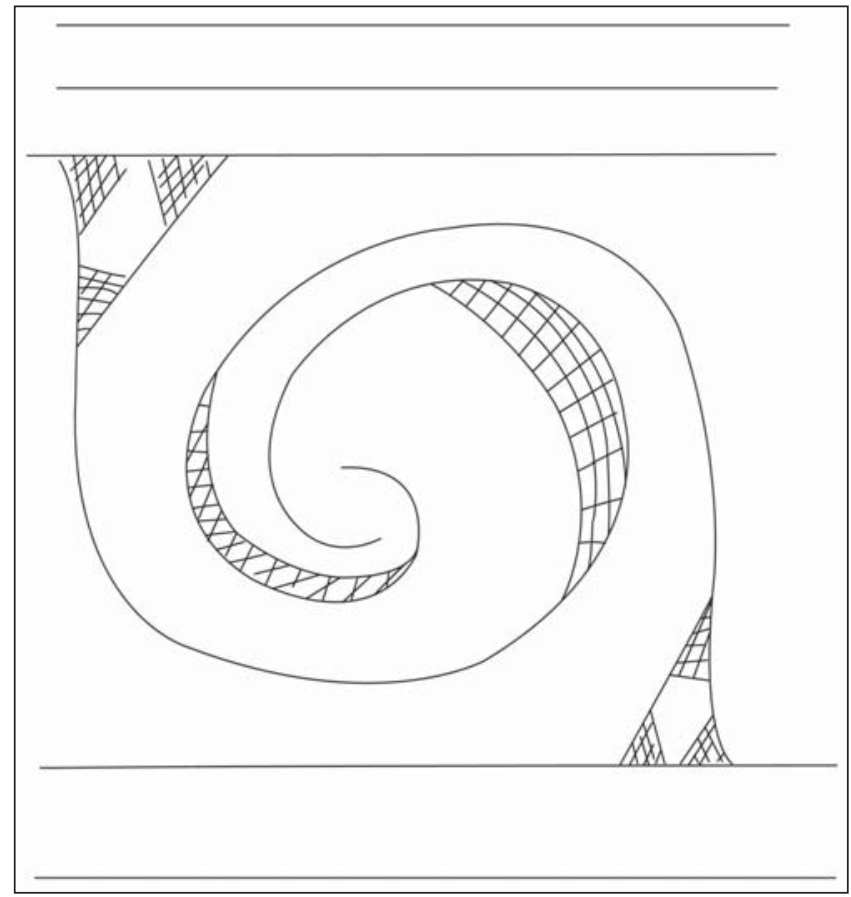

Figure 4. Decorative elements on Wilder Engraved, var. unspecified bottle from the Roger Attaway site (41HP15).

ESTIMATED VOLUME (IN LITERS): 0.5

DECORATION (INCLUDING MOTIF AND ELEMENTS WHEN APPARENT): The top of the vessel body has three horizontal engraved lines, and there are two horizontal engraved lines above the vessel base. Between these horizontal line are four curvilinear and hooked arm engraved elements that begin and end at upper and lower engraved pendant triangles with cross-hatched corners. Each of the curvilinear engraved lines have a wider cross-hatched zone across from the hooked arm elements (Figure 4).

PIGMENT USE AND LOCATION ON VESSEL: none

TYPE AND VARIETY (IF KNOWN): Wilder Engraved, var. unspecified 
SITE NAME OR SITE NUMBER: Roger Attaway

VESSEL NO.: 2

VESSEL FORM: Carinated bowl

NON-PLASTICS AND PASTE: grog

RIM AND LIP FORM: Direct rim and rounded lip

CORE COLOR: $\mathrm{G}$ (fired in a reducing environment and cooled in the open air)

INTERIOR SURFACE COLOR: grayish-brown

EXTERIOR SURFACE COLOR: brown

WALL THICKNESS (IN MM): rim, $5.9 \mathrm{~mm}$

INTERIOR SURFACE TREATMENT: smoothed

EXTERIOR SURFACE TREATMENT: burnished

HEIGHT (IN CM): 8.2

ORIFICE DIAMETER (IN CM): 14.6

DIAMETER AT BOTTOM OF RIM OR NECK (IN CM): 14.5

BASE DIAMETER (IN CM) AND SHAPE OF BASE: 6.4; circular and flat

ESTIMATED VOLUME (IN LITERS): 0.7

DECORATION (INCLUDING MOTIF AND ELEMENTS WHEN APPARENT): The rim has an engraved continuous scroll motif repeated four times around the vessel. The scroll lines begin and end at a vertical engraved line with upper and lower excised pendant triangles. The upper and lower scroll fill zones have excised brackets and columns forming two negative ovals per scroll fill zone (Figure 5).

PIGMENT USE AND LOCATION ON VESSEL: white clay pigment in the engraved lines

TYPE AND VARIETY (IF KNOWN): Ripley Engraved, var. Carpenter

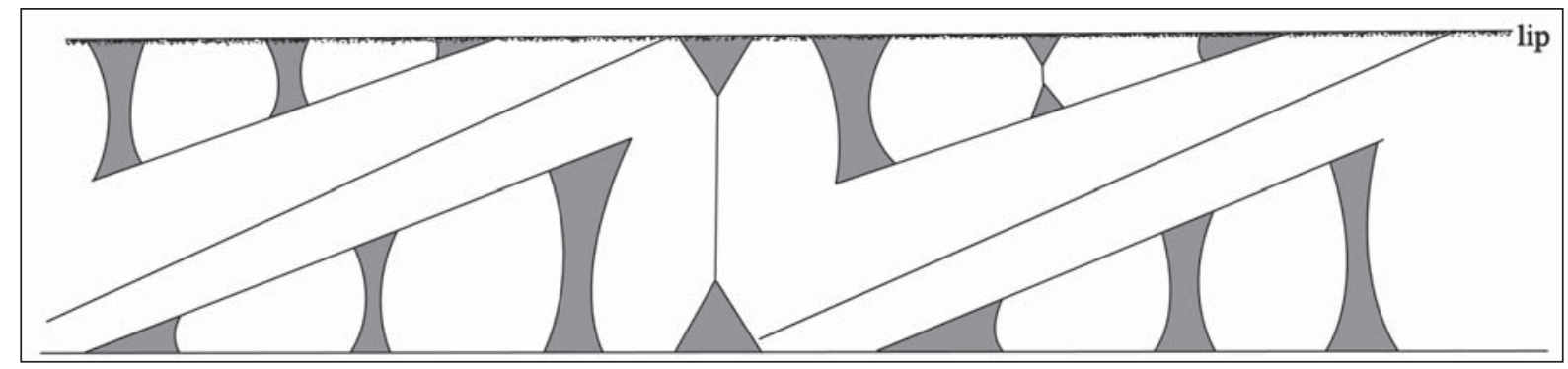

Figure 5. Decorative elements on Ripley Engraved, var. Carpenter carinated bowl from the Roger Attaway site (41HP15). 
SITE NAME OR SITE NUMBER: Roger Attaway

VESSEL NO.: 3

VESSEL FORM: Bottle

NON-PLASTICS AND PASTE: grog

RIM AND LIP FORM: Everted rim and rounded lip

CORE COLOR: $\mathrm{F}$ (fired in a reducing environment and cooled in the open air)

INTERIOR SURFACE COLOR: red at the neck

EXTERIOR SURFACE COLOR: red

WALL THICKNESS (IN MM): rim, $4.6 \mathrm{~mm}$

INTERIOR SURFACE TREATMENT: none

EXTERIOR SURFACE TREATMENT: smoothed

HEIGHT (IN CM): 22.5

ORIFICE DIAMETER (IN CM): 5.2

DIAMETER AT BOTTOM OF RIM OR NECK (IN CM): 9.2; maximum body diameter is $15.0 \mathrm{~cm}$.

BASE DIAMETER (IN CM) AND SHAPE OF BASE: 6.5; circular and flat

ESTIMATED VOLUME (IN LITERS):

DECORATION (INCLUDING MOTIF AND ELEMENTS WHEN APPARENT): The exterior surface, as well as the interior surface at the neck, has a red clay slip. There is also a single horizontal engraved line at the juncture of the bottle neck and the vessel body.

PIGMENT USE AND LOCATION ON VESSEL: none

TYPE AND VARIETY (IF KNOWN): Unidentified fine ware 
SITE NAME OR SITE NUMBER: Roger Attaway

VESSEL NO.: 4

VESSEL FORM: Jar

NON-PLASTICS AND PASTE: grog

RIM AND LIP FORM: Everted rim and rounded, exterior folded lip

CORE COLOR: F (fired in a reducing environment and cooled in the open air)

INTERIOR SURFACE COLOR: yellowish-brown; fire clouds on the rim; organic residue on the rim

EXTERIOR SURFACE COLOR: yellowish-brown; fire clouds on the rim, body, and base

WALL THICKNESS (IN MM): rim, $4.8 \mathrm{~mm}$; body, $4.9 \mathrm{~mm}$

INTERIOR SURFACE

TREATMENT: smoothed

EXTERIOR SURFACE

TREATMENT: none

HEIGHT (IN CM): 15.4

ORIFICE DIAMETER

(IN CM): 12.0

DIAMETER AT BOTTOM OF RIM OR NECK (IN CM): 10.5

BASE DIAMETER (IN CM) AND SHAPE OF BASE: 6.5 ; circular and flat

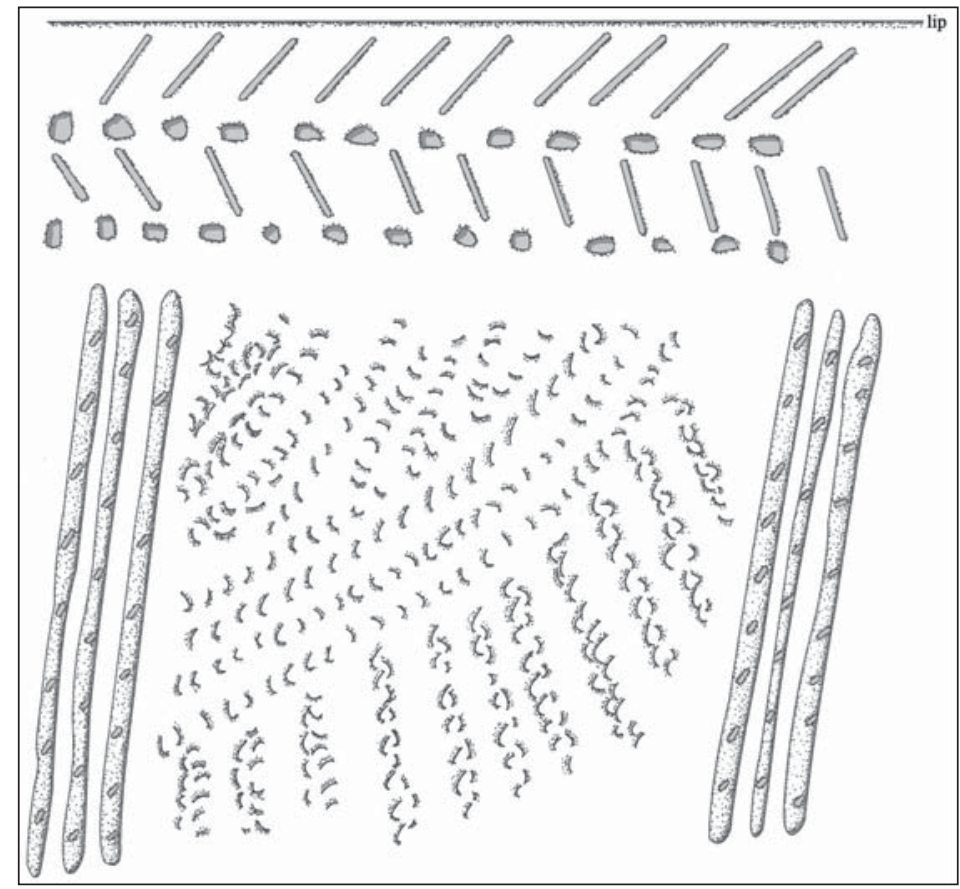

Figure 6. Incised-punctated-appliqued-pinched jar from the Roger Attaway site (41HP15).

ESTIMATED VOLUME (IN LITERS): 1.1

DECORATION (INCLUDING MOTIF AND ELEMENTS WHEN APPARENT): The vessel rim is decorated with diagonal incised lines pitched in opposing directions that are separated by a single horizontal row of tool punctations; there is also a single row of tool punctations at the rim-body juncture. The vessel body is divided into four panels by four sets of three closely spaced vertical appliqued fillets. The panels themselves are decorated with three sets of diagonal opposed pinched rows (Figure 6).

PIGMENT USE AND LOCATION ON VESSEL: none

TYPE AND VARIETY (IF KNOWN): Unidentified utility ware 
SITE NAME OR SITE NUMBER: Roger Attaway

VESSEL NO.: 5

VESSEL FORM: Carinated bowl

NON-PLASTICS AND PASTE: grog

RIM AND LIP FORM: Direct rim and rounded, exterior folded lip

CORE COLOR: F (fired in a reducing environment and cooled in the open air)

INTERIOR SURFACE COLOR: brown

EXTERIOR SURFACE COLOR: brown

WALL THICKNESS (IN MM): rim, $5.9 \mathrm{~mm}$

INTERIOR SURFACE TREATMENT: smoothed

EXTERIOR SURFACE TREATMENT: smoothed

HEIGHT (IN CM): 13.5

ORIFICE DIAMETER (IN CM): 23.5

DIAMETER AT BOTTOM OF RIM OR NECK (IN CM): 24.0

BASE DIAMETER (IN CM) AND SHAPE OF BASE: 7.5; circular and flat

ESTIMATED VOLUME (IN LITERS): 2.8

DECORATION (INCLUDING MOTIF AND ELEMENTS WHEN APPARENT): The rim is decorated with an engraved slanted scroll and circle repeated four times around the vessel. The central circle element has a smaller circle within it that has an equal-arm cross element with hatched pendant triangles at the top of the cross lines. The upper and lower scroll fill zones each have three negative oval elements outlined by crosshatched engraved brackets and triangle elements (Figure 7).

PIGMENT USE AND LOCATION ON VESSEL: white clay pigment in the engraved lines

TYPE AND VARIETY (IF KNOWN): Ripley Engraved, var. Galt

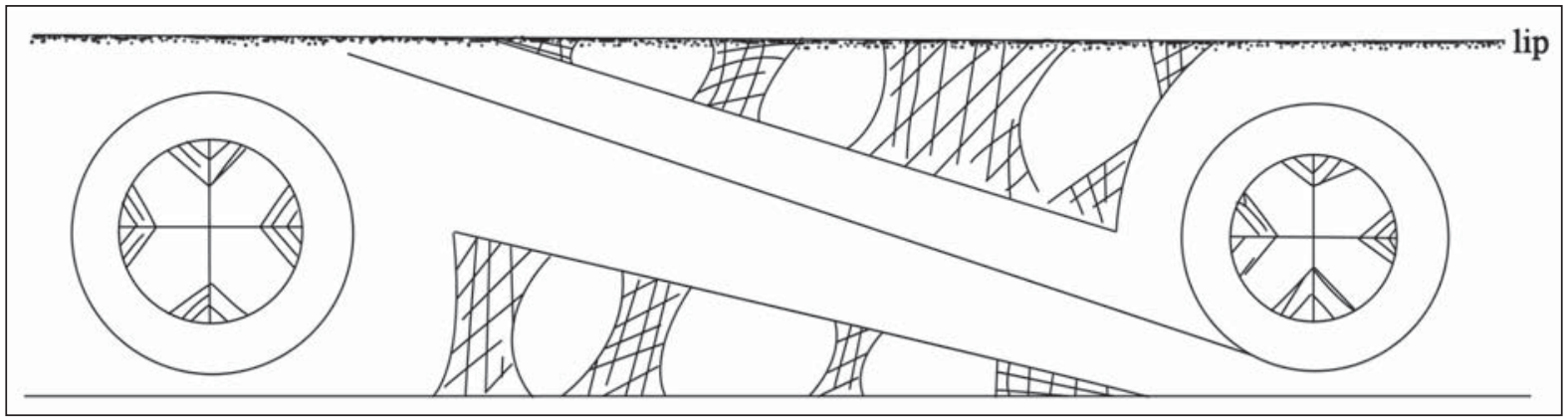

Figure 7. Decorative elements on Ripley Engraved, var. Galt carinated bowl from the Roger Attaway site. 


\section{SUMMARY AND CONCLUSIONS}

The E. B. Minter Farm (41HP2) vessels are from a Middle Caddo period (ca. A.D. 1200-1400) burial associated with Sanders phase occupations in the upper Red, Sulphur, Big Cypress, and Sabine River basins. All four vessels from Burial 1 are grog-tempered, and include a plain bowl and a plain bottle as well as two Sanders Engraved carinated bowls with diagonal opposed engraved lines on their rim panels.

On the other hand, the five ceramic vessels from the Roger Attaway site (41HP15) are from a Titus phase (ca. A.D. 1430-1680) burial context. The vessels, all grog-tempered, include a red-slipped bottle, an incisedpunctated-appliqued jar, a Wilder Engraved, var. unspecified bottle, and two Ripley Engraved carinated bowls of var. Carpenter or var. Galt.

\section{ACKNOWLEDGMENTS}

Lance Trask and Sandra Hannum prepared the figures in this article. Thanks to Marybeth Tomka at the Texas Archeological Research Laboratory at The University of Texas at Austin for access to the vessel collections.

\section{REFERENCES CITED}

Jackson, A. T.

1931 Excavation of a Burial Site on E. B. Minter Farm, 6 Miles N.W. of Weaver, Hopkins County, Texas. MS on file, Texas Archeological Research Laboratory, The University of Texas at Austin. 